\title{
Comparison of digestibility parameters of commercial dry dog foods with different contents
}

\author{
[Comparação dos parâmetros de digestibilidade de alimentos secos comerciais para \\ cães com diferentes conteúdos] \\ O. Kahraman, F. Inal
}

Faculty of Veterinary Medicine - Selçuk University - Konya, Turkey

\begin{abstract}
This study was aimed to evaluate and compare the nutrient digestibility of grain-inclusive and grain-free commercial dry dog foods using the method of total fecal collection and also explore their effects on fecal consistency. 21 different foods, including 14 grain-inclusive ( 7 grain-chicken meat, 7 grain-lamb meat) and 7 grain-free were investigated. 12 adult Golden retriever dogs (age $3-4$ years, body weight $=22.5 \pm 1.7 \mathrm{~kg}$ ) were divided into 3 groups. The results of digestibility trials indicated that the grain-lamb meat foods showed the highest digestibility of dry matter, organic matter, and crude fiber. Overall, in the graininclusive and grain-free group evaluation, grain-inclusive foods showed higher digestibility of crude fibers while grain-free foods had higher ether extract digestibility whereas the differences in the scores of fecal consistencies between the groups were insignificant. Contrary to popular belief, grain-inclusive foods were more digestive than grain-free foods in terms of dry matter and organic matter. There are studies involving starch sources in the dog food formulations, but there is a need to study the digestibility of complete dog food to supply them with adequate nutrients. Also, each diet should be assessed based on its overall nutrient profile and digestibility rather than individual ingredients.
\end{abstract}

Keywords: dog food, digestibility, grain-free, meat sources

\section{RESUMO}

Este estudo teve como objetivo avaliar e comparar as digestibilidades de nutrientes de alimentos secos para cães comerciais, com grãos e livres de grãos, usando o método de coleta fecal total, bem como explorar seus efeitos na consistência fecal. Vinte e um alimentos diferentes, incluindo 14 grãos inclusivos (sete grãos de carne de frango, sete grãos de carne de cordeiro) e sete livres de grãos, foram investigados. Doze cães Golden Retriever adultos (idade de três-quatro anos, peso corporal $=22,5 \pm 1,7 \mathrm{~kg}$ ) foram divididos em três grupos. Os resultados dos ensaios de digestibilidade indicaram que os alimentos cárneos de cordeiro apresentaram as maiores digestibilidades de matéria seca, matéria orgânica e fibra bruta. Em geral, na avaliação do grupo com grãos inclusivos e do grupo sem grãos, os alimentos com grãos inclusivos mostraram maior digestibilidade das fibras brutas, enquanto os alimentos sem grãos tiveram maior digestibilidade do extrato etéreo; já as diferenças nos escores de consistência fecal entre os grupos foram insignificantes. Ao contrário da crença popular, os alimentos com inclusão de grãos eram mais digestivos do que os sem grãos, em termos de matéria seca e matéria orgânica. Existem estudos envolvendo fontes de amido em formulações de rações, mas é necessário estudar a digestibilidade de rações completas para fornecer nutrientes adequados. Além disso, cada dieta deve ser avaliada com base em seu perfil geral de nutrientes e digestibilidade, em vez de ingredientes individuais.

Palavras-chave: ração para cães, digestibilidade, sem grãos, fontes de carne

Recebido em 24 de agosto de 2020

Aceito em 27 de outubro de 2020

E-mail: vetoguzhan90@gmail.com 


\section{INTRODUCTION}

The pet food sector is growing rapidly all over the world, with a demand for high-quality food from the dog owners. With this demand, ways are being sought to increase the quality of the food to provide healthy and balanced nutrition for the dogs (Cipollini, 2008; Başer and Yalçın, 2017). Palatability and digestibility are important issues in dog nutrition because they affect the intake and evaluation of the nutrients necessary for animal health (Crane et al., 2000).

Despite the importance given to the nutrient content of dog foods, there is only limited information about the digestibility of foods (Cipollini, 2008). Besides being loved and consumed by the animals, it is important to regularly analyze the dog food and also determine the quality of its nutrients declared by the food manufacturers along with the digestibility trials since the nutrient contents written on the label of food package declared by the manufacturers do not always match with the nutrient analysis (Rolinec et al., 2016).

Digestibility studies are conducted to evaluate the effectiveness of the food on the maintenance, growth, and body condition of the dogs. Generally, a digestibility trial is done by determining the amount of digested and absorbed nutrients from the calculated amount of food consumed, where digestibility depends on various factors such as breed and age of the dog, type of food, level of cooking/gelatinization of food, and composition of the formula (Brambillasca et al., 2010).

High digestibility of diet or food is manifested by a small amount of fecal excretion and its hard consistency (Sunvold et al., 1995b). Less digestible commercial foods may undergo higher fermentation by the colonic bacteria, resulting in excessive gas production and soft feces, the results of which are uncomfortable for both dogs and their owners. Especially, the large and giant dog breeds are more sensitive and have higher moisture content in their stool, resulting in softer stools compared to the medium and small dog breeds (Weber et al., 2003).

Carbohydrates are generally used as an energy source, but dogs do not need carbohydrates as nutrients (Romsos et al., 1976) because they can meet their glucose requirement for maintenance and growth purposes by gluconeogenesis as long as there is a sufficient amount of fats and proteins in the food. However, carbohydrates are important components that constitute $30 \%$ to $60 \%$ of dry dog foods and $30 \%$ of the canned foods. Most of these carbohydrates in foods come from the starch (Beynen, 2014).

Diseases in dogs have increased by $80 \%$ in recent years, and studies have shown processed foods to be responsible for this (Souliere, 2014).hence, the owners try to feed healthier food to their dogs by focusing too much on advertisements and labels on commercial foods such as "grain-free and gluten-free". There are a lot of debates happening on whether it is best to feed the dogs with foods containing grains or not. While mentioning about the quality of food, it is also important that it has high digestibility, apart from containing sufficient and balanced nutrients. Thus, this study was aimed to compare the grain-inclusive with grainfree foods to determine if the grain-free foods were as digestible as the grain-inclusive ones using the method of total fecal collection and also by scoring the fecal consistency of the dogs.

\section{MATERIALS AND METHODS}

A total number of 21 different commercial dry dog foods (7 lamb-grain, 7 chicken-grain, and 7 grain-free) were used in this study. 12 female $(n=6)$ and male $(n=6)$ adult healthy Golden retriever breed dogs aged about 3-4 years old, with the bodyweights of $22.5 \pm 1.7 \mathrm{~kg}$ were used in this study. They were housed in the individual concrete kennels with a closed $(190 \times 190 \mathrm{~cm})$ and open area $(510 \times 230 \mathrm{~cm})$ in Selcuk University Faculty of Veterinary Medicine, hümeyra Özgen Research and Application Farm, dog research unit. Three groups were created in this study, where each group consisted of $4 \mathrm{dogs}$ having similar average body weight with an equivalent number of females and males.

To determine the nutrient content and digestibility of foods, dry matter (DM), crude ash (CA), ether extract (EE), crude fiber (CF), and crude protein (CP) were analyzed (Akkılıç and Sürmen, 1979) in foods and collected feces. Also, the starch contents in the foods were determined by the polarimetric method (Association..., 2003). The total fecal collection method used here was described by Felix et al. (2012). The nutrient 
digestibility of each food was determined in 4 dogs. The daily amount of food given to the animals was adjusted according to their body weights and movement status, as described on the food package label. Water was always provided in the amount that they could drink.

An 8-day adaptation period was applied for each food, and daily feces were collected for the next five days. Feces were weighed and kept in a freezer $\left(-18^{\circ} \mathrm{C}\right)$, which were then thawed and dried in a $70^{\circ} \mathrm{C}$ oven for $60 \mathrm{~h}$, after which the dry matter was determined. Dried feces were ground using a $1.0 \mathrm{~mm}$ diameter sieve, and the same nutrient analysis that was performed in the foods was also applied to the feces. Digestibility was calculated using the nutrient analysis results of the foods and feces. The formula used were as follows (Crane et al., 2000):

\section{$\mathrm{DMD} \%=(\mathrm{DMF}-\mathrm{DMFE}) / \mathrm{DMF} \times 100$}

$\mathrm{ND} \%=(\mathrm{NF}-\mathrm{NFE}) / \mathrm{NF} \times 100$

DMD: dry matter digestibility of food, DMF: dry matter of food, DMFE: dry matter of feces, ND: nutrient digestibility, NF: nutrient in food, NFE: nutrient in feces

The fecal consistency was determined daily for the last five days of the digestibility trial, just before collecting the feces. Scoring was done according to the 1-5 system described by Strickling et al. (2000), and the grading was as follows:

Grade 1: more than two-thirds of the feces in defecation was liquid-like diarrhea, where the feces did not have a form and appeared as a squirt. Grade 2: soft-liquid feces; an intermediate between soft and liquid feces.

Grade 3: more than two-thirds of the feces in defecation was soft.

Grade 4: firm-soft feces; an intermediate between the grades of the firm and soft.

Grade 5: more than two-thirds of the feces in defecation were firm and shaped like an intestinal throat.

Three groups were created based on the meat sources in foods, which included grain-chicken meat, grain-lamb meat, and grain-free meat. Statistical analyses were performed between the grain-inclusive and grain-free groups. Since the sources of animal protein in grain-free foods were different (lamb meat, chicken, fish meal, deer, rabbit, etc.), they were not divided into the subgroups. SPPS V.22 statistical software was used to evaluate the data. The Independent t-test (Student's t-test) was performed to compare two groups, and when the prerequisites were not met, the Mann Whitney-U test was performed while the TukeyhSD test was used to compare three groups and if not met with the prerequisites, then the Bonferroni-Dunn test was used.

\section{RESULTS AND DISCUSSIONS}

Nutrient contents varied according to the formulations of foods and different brands. No nutrients were similar between the grain-inclusive and grain-free groups. The levels of metabolic energy (ME, $\mathrm{kcal} / \mathrm{kg}$ ) produced from the foods were calculated using at water factors (Table 1).

The differences in dry matter digestibility (DMD), organic matter digestibility (OMD), and crude fiber digestibility (CFD) between the three groups (grain-chicken meat, grain-lamb meat, grain-free) were found to be significant (Table 2). The differences between the grain-free and grain-lamb meat foods were significant for DMD and OMD (Table 3). The CFD was found to be different among all the three groups.

Many factors affect the digestibility such as the sources of ingredient, level of cellulose, presence of anti-nutritional factors, level of crude ash, and heat treatments applied during the food production (Gilani et al., 2005; hill et al., 2009; Oliveira et al., 2012). In this study, differences were determined in terms of DMD, OMD, and CFD between the commercial grain-chicken, grain-lamb, and grain-free dog foods. The highest digestibility values were obtained in the grainlamb group (Table 3).

On comparing the grain-inclusive and grain-free foods, grain-free foods showed higher values of ether extract digestibility (EED), while graininclusive foods showed higher CFD (Table 3). The presence of higher levels of ether extract in the grain-free foods explains the high EED of the group. It is also estimated that high levels of ether extract can reduce fiber digestibility. The reason for the low levels of CFD in the grain-free group may be due to the vegetables included in the composition of dog foods. 
Table 1. The nutrient composition and metabolic energy (ME, $\mathrm{kcal} / \mathrm{kg}$ ) levels of the foods (\% DM)

\begin{tabular}{cccccccc}
\hline Dog food Group & DM & CA & EE & CF & CP & Starch & ME \\
\hline \multirow{5}{*}{ Grain-Chicken } & 93.54 & 7.34 & 10.86 & 5.28 & 29.93 & 42.73 & 3608.3 \\
& 95.5 & 7.77 & 11.69 & 4.57 & 28.77 & 37.07 & 3659.8 \\
& 94.64 & 10.9 & 8.83 & 4.99 & 28.74 & 31.37 & 3376.6 \\
& 94.52 & 5.39 & 13.45 & 5.23 & 24.5 & 44.77 & 3818.2 \\
& 92.42 & 6.68 & 15.67 & 3.85 & 34.13 & 33.86 & 3949 \\
Grain-Lamb & 94.37 & 9.67 & 9.92 & 7.42 & 38.13 & 23.38 & 3391.8 \\
& 94.41 & 6.3 & 9.09 & 5.82 & 28.49 & 43.9 & 3532.1 \\
& 93.5 & 6.18 & 9.58 & 5.07 & 30.66 & 42.9 & 3591.2 \\
& 95.22 & 8.94 & 11.84 & 5.05 & 28.59 & 34.4 & 3607.5 \\
& 95.8 & 6.91 & 10.27 & 4.35 & 21.27 & 42.52 & 3624.6 \\
Grain-free & 93.1 & 9.63 & 10.48 & 5.9 & 29.25 & 36.24 & 3479 \\
& 95.93 & 8.33 & 16.68 & 4.46 & 28.4 & 29.05 & 3902.7 \\
& 95.01 & 7.08 & 7.22 & 11.8 & 25.33 & 50.75 & 3184.1 \\
& 94.88 & 6.68 & 11.86 & 6.29 & 30.99 & 38.09 & 3646.6 \\
& 94.37 & 7.5 & 13.98 & 6.35 & 27.64 & 45.83 & 3727 \\
& 95.54 & 9.51 & 16.41 & 3.1 & 41.4 & 20.6 & 3896.9 \\
& 92.87 & 8.42 & 11.27 & 3.37 & 36.05 & 31.32 & 3662.4 \\
& 94.67 & 9.63 & 15.59 & 4.61 & 45.27 & 20.07 & 3796.9 \\
& 94.7 & 9.37 & 15.68 & 3.79 & 43.48 & 19.63 & 3841.5 \\
& 94.53 & 6.79 & 12.55 & 3.1 & 28.19 & 37.47 & 3797.6 \\
& 96.01 & 7.04 & 13.08 & 4.51 & 36.96 & 27.72 & 3695.2 \\
\hline
\end{tabular}

$\mathrm{DM}=$ Dry matter; $\mathrm{CA}=$ Crude ash $\mathrm{EE}=$ Ether extraction $\mathrm{CF}=$ Crude fiber $\mathrm{CP}=$ Crude protein $\mathrm{ME}=$ metabolic energy as the amount of $\mathrm{kcal} / \mathrm{kg}$ in DM.

Table 2. The evaluation of nutrient digestibility of foods in three groups (\%)

\begin{tabular}{|c|c|c|c|c|c|}
\hline & Group & $\mathrm{n}$ & $\bar{x}$ & SEM & $P$ \\
\hline \multirow{3}{*}{ DMD } & Grain-chicken & 28 & $79.29^{\mathrm{ab}}$ & 0.88 & \multirow{3}{*}{0.043} \\
\hline & Grain-lamb & 28 & $80.84^{\mathrm{a}}$ & 0.67 & \\
\hline & Grain-free & 28 & $77.41^{\mathrm{b}}$ & 1.21 & \\
\hline \multirow{3}{*}{ OMD } & Grain-chicken & 28 & $82.71^{\mathrm{ab}}$ & 0.62 & \multirow{3}{*}{0.002} \\
\hline & Grain-lamb & 28 & $85.11^{\mathrm{a}}$ & 0.54 & \\
\hline & Grain-free & 28 & $81.29^{b}$ & 1.02 & \\
\hline \multirow{3}{*}{ EED } & Grain-chicken & 28 & 95.2 & 0.36 & \multirow{3}{*}{0.052} \\
\hline & Grain-lamb & 28 & 95.08 & 0.94 & \\
\hline & Grain-free & 28 & 96.96 & 0.25 & \\
\hline \multirow{3}{*}{ CFD } & Grain-chicken & 28 & $36.7^{b}$ & 2.72 & \multirow{3}{*}{$<0.001$} \\
\hline & Grain-lamb & 28 & $48.69^{a}$ & 3.39 & \\
\hline & Grain-free & 28 & $23.83^{\mathrm{c}}$ & 3.95 & \\
\hline \multirow{3}{*}{ CPD } & Grain-chicken & 28 & 80.39 & 0.78 & \multirow{3}{*}{0.594} \\
\hline & Grain-lamb & 28 & 81.41 & 0.78 & \\
\hline & Grain-free & 28 & 80.22 & 1.07 & \\
\hline
\end{tabular}

$\mathrm{DMD}=$ Dry matter digestibility; OMD = Organic matter digestibility; EED = Ether extract digestibility; CFD = Crude fiber digestibility; $\mathrm{CPD}=$ Crude protein digestibility. $\mathrm{SEM}=$ standard error of the mean. ${ }^{\mathrm{a}, \mathrm{b}, \mathrm{c}}$ Values in the same column that are not sharing a common superscript differ significantly $(P<0.05) . \mathrm{n}=7$ grain-free foods $\mathrm{X} 4 \operatorname{dogs}, 7$ grain-chicken foods X 4 dogs, 7 grain-lamb foods X 4 dogs.

The grain-lamb foods showed higher DMD and OMD compared to other groups, which can be explained by the fact that starch was higher in the composition of their food. Indeed, the digestibility of starch in dog food was reported between 95-
99\% (Walker et al., 1994; Murray et al., 1999; Cipollini, 2008), whereas the starch digestibility of grain flours was shown to be $99-100 \%$ (Bednar et al., 2001). 
Table. 3 The evaluation of nutrient digestibility of foods in the total grain-inclusive and grain-free groups $(\%)$

\begin{tabular}{|c|c|c|c|c|c|}
\hline & Group & $\mathrm{n}$ & $\bar{x}$ & SEM & $P$ \\
\hline \multirow{2}{*}{ DMD } & Grain-inclusive & 56 & 80.06 & 0.56 & \multirow{2}{*}{0.115} \\
\hline & Grain-free & 28 & 77.41 & 1.21 & \\
\hline \multirow{2}{*}{ OMD } & Grain-inclusive & 56 & 83.91 & 0.44 & \multirow{2}{*}{0.053} \\
\hline & Grain-free & 28 & 81.29 & 1.02 & \\
\hline \multirow{2}{*}{ EED } & Grain-inclusive & 56 & $95.14^{\mathrm{b}}$ & 0.5 & \multirow{2}{*}{$<0.001$} \\
\hline & Grain-free & 28 & $96.96^{\mathrm{a}}$ & 0.25 & \\
\hline \multirow{2}{*}{ CFD } & Grain-inclusive & 56 & $42.7^{\mathrm{a}}$ & 2.3 & \multirow{2}{*}{$<0.001$} \\
\hline & Grain-free & 28 & $23.83^{\mathrm{b}}$ & 3.95 & \\
\hline \multirow{2}{*}{ CPD } & Grain-inclusive & 56 & 80.9 & 0.55 & \multirow{2}{*}{0.375} \\
\hline & Grain-free & 28 & 80.22 & 1.07 & \\
\hline
\end{tabular}

$\overline{\mathrm{DMD}}=$ Dry matter digestibility; OMD = Organic matter digestibility; EED = Ether extract digestibility; CFD= Crude fiber digestibility; $\mathrm{CPD}=$ Crude protein digestibility. $\mathrm{SEM}=$ standard error of the mean. ${ }^{\mathrm{a}, \mathrm{b}}$ Values in the same column that are not sharing a common superscript differ significantly $(P<0.001) .28=7$ grain-free foods $\mathrm{X} 4$ dogs. $56=14$ grain-inclusive foods $\mathrm{X} 4 \mathrm{dogs}$.

These results were expected since rice and corn, the grains mostly used in dog foods, have lower cellulose levels with higher digestibility. Carciofi et al. (2008) achieved the highest levels of DMD and OMD from tapioca and rice by-products. The average CP levels of grain-chicken, grain-lamb, and grain-free dog foods were determined to be $30.38,27.78$, and $37 \%$, respectively (Table 1 ). As reported by Hill et al. (2009) and Schauf et al. (2018), the crude protein digestibility (CPD) were not found to be higher in the group that had a higher protein level. In contrast, grain-lamb foods with the lowest $\mathrm{CP}$ level showed higher CPD, although not significant (Table 2), whereas grainfree foods showed the highest CP content with lower CPD (Table 3). Thus, the grain-free foods with a lower proportion of animal protein sources or vegetable proteins used instead of grains showed lesser digestion than the grain proteins. Another reason for this could be the presence of high-quality protein sources along with a balanced amino acid composition in the graininclusive foods.

Grain-free dog foods are generally not low-carb foods, contrary to popular belief. Some of them have carbohydrate levels similar to that of the grain-inclusive dog foods (Beynen, 2014). We determined that some grain-free foods had as much starch as grain-inclusive dog foods (Table 1). Additionally, grain-free foods with low starch content were also identified. Hill et al. (2009) prepared high $(45 \%)$ and low $(13 \%)$ carbohydrate diets and evaluated their digestibility in dogs and obtained higher DMD, CPD, and EED in a low carbohydrate diet. However, researchers here compared only two foods. Similarly, Chiofalo et al. (2019) determined a higher CPD in the graininclusive dog food that contained high protein and low carbohydrates. In this study, though grainfree foods were having higher protein and lower starch levels, their digestibility were not as high as the grain-inclusive ones.

One of the reasons DMD, OMD, and CFD were lower in the grain-free foods than that of the grainlamb foods is because of the high CA level. Digestibility can vary greatly from one brand to another, and even between the products within the same brand. Since there is no legal obligation to provide information on the digestibility of the product, pet owners rely on the price and popularity of the food (Daumas et al., 2014). Although the commercial dog foods guarantee the nutrient levels printed on the package, their digestibility can have a large difference (Huber $e t$ al., 1985).

The results of fecal consistency scoring were performed in the last five days of the trial and are presented in Table 4. There were no significant differences found between the groups $(\mathrm{P}>0.05)$. According to the multiple comparison test, the differences between the fecal scores of the groups were not significant. All recorded scores were in the ideal score range (3-5) for the dogs. Many factors in the food affect fecal consistency, such as their sources, CF level, fiber type, presence of anti-nutritional factors, and CA levels (Clapper $e t$ al., 2001; Gilani et al., 2005; Oliveira et al., 2012). Zentek et al. (2004) reported that if dogs eat foods or diets having high dry matter content 
then they produce feces with a hard consistency. The dry matter levels of commercial dry dog foods used in this study were around $94 \%$ with similar values in all the groups (Table 1). For this reason, it was normal to observe no significant difference between the fecal consistencies (Table
4). Chiofalo et al. (2019) also did not determine a significant difference in terms of fecal consistency between the dog groups that consumed graininclusive and grain-free foods, which was consistent with this study.

Table 4. Fecal consistency scores in the dogs

\begin{tabular}{|c|c|c|c|c|}
\hline \multicolumn{5}{|c|}{ Fecal scores of three groups (Grain-free, Grain-lamb meat, grain-chicken meat) } \\
\hline & $\mathrm{n}$ & Score $(\bar{x})$ & SEM & $P$ \\
\hline Grain-chicken & 28 & 3.89 & 0.08 & \multirow{3}{*}{0.123} \\
\hline Grain-lamb & 28 & 4.12 & 0.07 & \\
\hline Grain-free & 28 & 4.04 & 0.09 & \\
\hline \multicolumn{5}{|c|}{ Fecal scores of total grain-inclusive (Grain-lamb meat, grain-chicken meat) and grain-free foods } \\
\hline Grain-inclusive & 56 & 4.01 & 0.06 & \multirow{2}{*}{0.83} \\
\hline Grain-free & 28 & 4.04 & 0.09 & \\
\hline
\end{tabular}

Fecal consistency scores: on a scale of 1 to 5 . Scale 1 - liquid feces and scale 5 - firm feces. SEM= standard error of the mean. $28=7$ grain-free foods $X 4$ dogs. $56=14$ grain-inclusive foods $X 4$ dogs.

The relationship between fiber levels of commercial foods, digestibility, amount of feces excreted, and fecal consistency was reported in the previous studies (Burrows et al., 1982; Fahey et al., 1990a, 1990b). It is known that the foods containing high fibers had lower digestibility. With the exceptions of the foods used in this study, in general, the dog foods have suitable $\mathrm{CF}$ content. During this study, the feces were not observed to be of very low quality or in a liquid form.

\section{CONCLUSION}

Digestibility trials are essential for evaluating commercial dog foods after the nutrient analysis is performed at a laboratory. Regardless of whether the animal is a dog or a cat, its body does not treat grains from other sources of carbohydrates differently. The results of this study indicated that the grain-inclusive commercial dog foods were more digestible than the grain-free foods while the fecal consistency scores of dogs remained similar in both the groups. Although grain-free foods are highly priced foods in the market, their nutritional benefits are yet to be proven. Hence, it is preferred for dogs to have nutritionally well-balanced and more economical grain-inclusive foods.

\section{ACKNOWLEDGEMENTS}

This study was created from a part of the $\mathrm{PhD}$ thesis named "Determination of Qualities and Digestibilities of Dry Dog Foods with Different
Content by Total Collection and In vitro Fermentation Parameters'. The study was approved and supported by Selcuk University, Academic Staff Training Program (ÖYP) Coordination Unit with project number ÖYP-101. This work was approved by the Selcuk University, Faculty of Veterinary Medicine, Experimental Animals Production and Research Center Ethics Committee under protocol number 2016/86. Also, the authors declare no conflict of interest.

\section{REFERENCES}

AKKILIÇ, M.; SÜRMEN, S. Yem maddeleri vehayvan besleme laboratuvar kitabı. Ankara: Ankara Üniversitesi Basımevi, 1979.

ASSOCIATION of official analytical chemists. Official methods of the AOAC. 7.ed. Gaithersburg: AOAC, 2003.

BAŞER, Ö.; YALÇIN, S. Determination of some quality characteristics in pet foods. Ank. Üniv. Vet. Fak. Derg., v.64, p.21-24, 2017.

BEDNAR, G.E.; PATIL, A.R.; MURRAY, S.M.; GRIESHOP, C.M. et al. Starch and fiber fractions in selected food and feed ingredients affect their small intestinal digestibility and fermentability and their large bowel fermentability in Vitro in a canine mode. Nutr. J., v.131, p.276-286, 2001.

BEYNEN, A.C. Grain-free pet foods. Creat. Comp., p.58-59, 2014. 
BRAMBILLASCA, S.; PURTSCHER, F.; BRITOS, A.; REPETTO, J.L. et al. Digestibility, fecal characteristics, and plasma glucose and urea in dogs fed a commercial dog food once or three times daily. Can. Vet. J., v.51, p.190, 2010.

BURROWS, C.F.; KRONFELD, D.S.; BANTA, C.A.; MERRITT, A.M. Effects of fiber on digestibility and transit time in dogs. Nutr. J., v.112, p.1726-1732, 1982.

CARCIOFI, A.C.; TAKAKURA, F.S.; OLIVEIRA, L.D.; TESHIMA, E. et al. Effects of six carbohydrate sources on dog diet digestibility and post-prandial glucose and insulin response. $J$. Anim. Physiol. Anim. Nutr., v.92, p.326-336, 2008.

CHIOFALO, B.; VITA, G.; PRESTI, V.L.; CUCINOTTA, S. et al. Grain free diets for utility dogs during training work: Evaluation of the nutrient digestibility and faecal characteristics. Anim. Nutr., v.5, p.297-306, 2019.

CIPOLLINI I. Pet food: quality and quality improvement. 2008. 87f. Thesis (Doctor in Scienze della Nutrizione e degli alimenti - Feed and Food Science) - Università di Bologna, IT.

CLAPPER, G.M.; GRIESHOP, C.M.; MERCHEN, N.R.; RUSSETT, J.C. et al. Ileal and total tract nutrient digestibilities and fecal characteristics of dogs as affected by soybean protein inclusion in dry, extruded diets. Anim. Sci. J., v.79, p.1523-1532, 2001.

CRANE，S.W.; GRIFFIN，R.W.; MESSENT, P.R. Introduction to commercial pet foods. Small Anim. Clinic. Nutr., p.111-126, 2000.

DAUMAS, C.; PARAGON, B.M.; THORIN, C.; MARTIN, L. et al. Evaluation of eight commercial dog diets. J. Nutr. Sci., v.3, p.1-5, 2014.

FAHEY JR, G.C.; MERCHEN, N.R.; CORBIN, J.E.; HAMILTON, A.K. et al. Dietary fiber for dogs: I. Effects of graded levels of dietary beet pulp on nutrient intake, digestibility, metabolizable energy and digesta mean retention time. Anim. Sci. J., v.68, p.4221-4228, 1990a.
FAHEY JR, G.C.; MERCHEN, N.R.; CORBIN, J.E.; HAMILTON, A.K. et al. Dietary fiber for dogs: II. Iso-total dietary fiber (TDF) additions of divergent fiber sources to dog diets and their effects on nutrient intake, digestibility, metabolizable energy and digesta mean retention time. Anim. Sci. J., v.68, p.4229-4235, 1990 b.

FELIX, A.P.; CARVALHO, M.P.; ALARCA, L.G. et al. Effects of the inclusion of carbohydrases and different soybean meals in the diet on palatability, digestibility and faecal characteristics in dogs. Anim. Feed Sci. Tech., v.174, p.182-189, 2012.

GILANI, G.S.; COCKELL, K.A.; SEPEHR, E. Effects of antinutritional factors on protein digestibility and amino acid availability in foods. J. AOAC Int, v.88, p.967-987, 2005.

HILL, S.R.; RUTHERFURD-MARKWICK, K.J.; RAVINDRAN, G.; UGARTE, C.E. et al. The effects of the proportions of dietary macronutrients on the digestibility, post-prandial endocrine responses and large intestinal fermentation of carbohydrate in working dogs. .N.Z. Vet. J., v.57, p.313-318, 2009.

HUBER, T.L.; WILSON, R.C.; MCGARITY, S.A.Variation in digestibility of dry foods with identical label guaranteed analysis. J. Am. Anim. hosp. Assoc., v.22, p.571-575, 1985.

MURRAY, S.M.; FAHEY JR, G.C.; MERCHEN, N.R.; SUNVOLD, G.D. et al. Evaluation of selected high-starch flours as ingredients in canine diets. J. Anim. Sci., v.77, p.2180-2186, 1999.

OLIVEIRA, L.D.; CARVALHO PICINATO, M.A. et al. Digestibility for dogs and cats of meat and bone meal processed at two different temperature and pressure levels. J. Anim. Physiol. Anim. Nutr., v.96, p.1136-1146, 2012.

ROLINEC, M.; BÍRO, D.; GÁLIK, B.; ŠIMKO, M. et al. The nutritive value of selected commercial dry dog foods. Acta Fytotech. Zootech., v.19, p.25-28, 2016.

ROMSOS, D.R.; BELO, P.S.; BENNINK, M.R.; BERGEN, W.G. et al. Effects of dietary carbohydrate, fat and protein on growth, body composition and blood metabolite levels in the dog. Nutr. J., v.106, p.1452-1464, 1976. 
SCHAUF, S.; SALAS-MANI, A.; TORRE, C. et $a l$. Effect of feeding ahigh-carbohydrate or ahighfat diet on subsequent food intake and blood concentration of satiety-related hormones in dogs. J. Anim. Physiol. Anim. Nutr., v.102, p.21-29, 2018.

SOULIERE, K.M. A study of the nutritional effect of grains in the diet of a dog. 2014. 29f. Thesi (Doctor in Animal and Veterinary Science) honors College, University of Maine, FL.

STRICKLING, J.A.; HARMON, D.L.; DAWSON, K.A.; GROSS, K.L. Evaluation of oligosaccharide addition to dog diets: influences on nutrient digestion and microbial populations. Anim. Feed. Sci. Tech., v.86, p.205-219, 2000.

SUNVOLD, G.D., FAHEY, G.C. JR., MERCHEN, N.R., TITGEMEYER, E.C., BOURQUIN, L.D., BAUER, L.L., REINHART G.A. Dietary fibre for dogs: IV. In vitro fermentation of selected fibre sources by dog fecal inoculum and in vivo digestion and metabolism of fiber-supplemented diets. J. Anim. Sci., v.73, p.1099-1109, 1995b.
WALKER, J.A.; HARMON, D.L.; GROSS, K.L.; COLLINGS, G.F. Evaluation of nutrient utilization in the canine using the ileal cannulation technique. Nutr. J., v.124, p.2672-2676, 1994.

WEBER, M.; MARTIN, L.; BIOURGE, V.; NGUYEN, P. et al. Influence of age and body size on the digestibility of a dry expanded diet in dogs. J. Anim. Physiol. Anim. Nutr., v.87, p.21-31, 2003.

ZENTEK, J.; FRICKE, S.; HEWICKERTRAUTWEIN, M.; EHINGER, B. et al. Dietary protein source and manufacturing processes affect macronutrient digestibility, fecal consistency, and presence of fecal Clostridium perfringens in adult dogs. Nutr. J., v.134, p.2158-2161, 2004. 